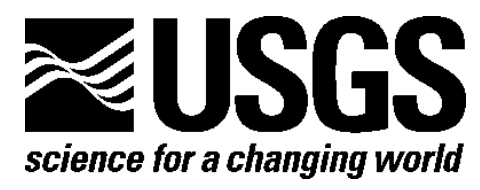

\title{
Geologic Criteria for the Assessment of Sedimentary Exhalative (Sedex) Zn-Pb-Ag Deposits
}

By Poul Emsbo

Open-File Report 2009-1209

U.S. Department of the Interior

U.S. Geological Survey 


\section{U.S. Department of the Interior \\ KEN SALAZAR, Secretary}

\section{U.S. Geological Survey \\ Suzette M. Kimball, Acting Director}

U.S. Geological Survey, Reston, Virginia 2009

For product and ordering information:

World Wide Web: http://www.usgs.gov/pubprod

Telephone: 1-888-ASK-USGS

For more information on the USGS - the Federal source for science about the Earth, its natural and living resources, natural hazards, and the environment:

World Wide Web: http://www.usgs.gov

Telephone: 1-888-ASK-USGS

Suggested citation:

Emsbo, Poul, 2009, Geologic criteria for the assessment of sedimentary exhalative (sedex) Zn-Pb-Ag deposits: U.S. Geological Survey Open-File Report 2009-1209, 21 p.

Any use of trade, product, or firm names is for descriptive purposes only and does not imply endorsement by the U.S. Government.

Although this report is in the public domain, permission must be secured from the individual copyright owners to reproduce any copyrighted material contained within this report. 


\section{Contents}

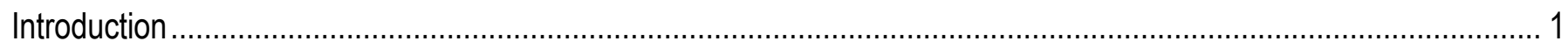

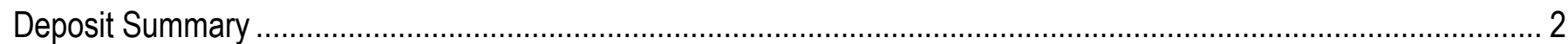

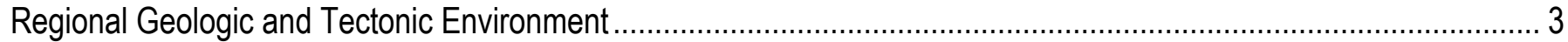

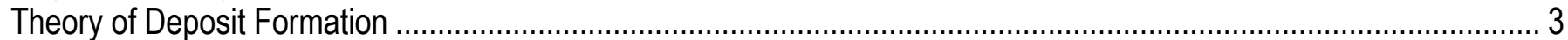

Source of Fluids Involved in Ore Component Transport .......................................................................... 3

Deduced Geologic Assessment Criteria.............................................................................................. 5

Sources of Ligands and Chemical Transport and Transfer Processes Involved in Ore Component Transport ............ 5

Deduced Geologic Assessment Criteria ............................................................................................

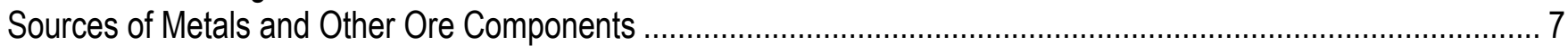

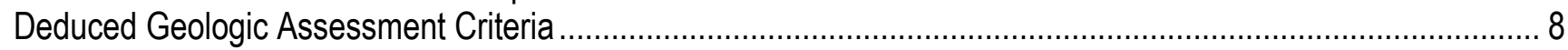

Fluid Drive, Including Thermal, Pressure, and Geodynamic Mechanisms ........................................................ 8

Sedimentary Compaction Model .................................................................................................... 8

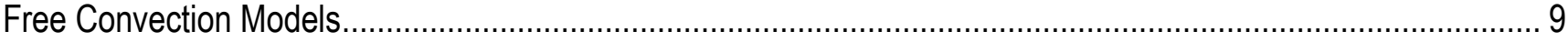

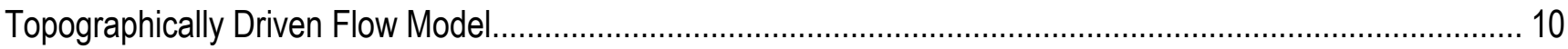

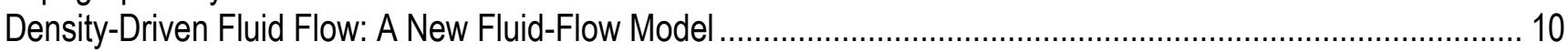

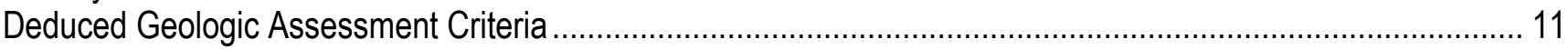

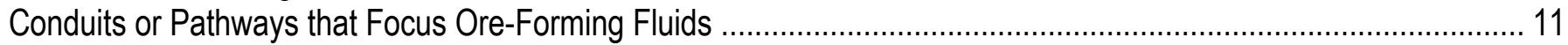

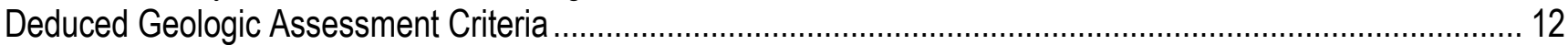

Nature of Traps and Wallrock Interaction that Trigger Ore Precipitation ......................................................... 12

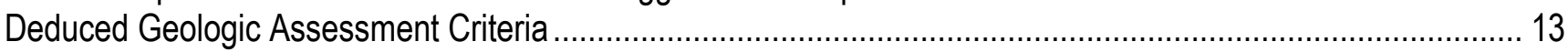

Structure and Composition of Residual Fluid Outflow Zones ....................................................................... 13

Deduced Geologic Assessment Criteria ………........................................................................................... 14

Hierarchy of Geologic Exploration and Resource Assessment Criteria ................................................................... 14

Geologic Criteria that Define Permissive Tracts...................................................................................... 15

Geologic Criteria Used to Evaluate the Prospectivity of Permissive Tracts......................................................... 16

Geologic Criteria that Map Favorability within Permissive Tracts ...................................................................... 17

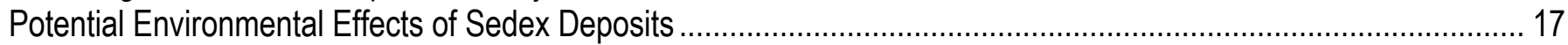

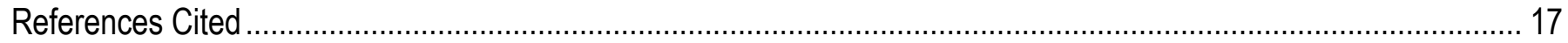

\section{Figures}

1. Map of six sedimentary basins that are known to contain a total endowment of more than $10 \mathrm{Mt}$ tons $\mathrm{Zn}+\mathrm{Pb}$ metal.

2. Block diagram showing geologic setting and geologic assessment criteria for sedex $\mathrm{Zn}-\mathrm{Pb}-\mathrm{Ag}$ deposits that are deduced form this synthesis 


\section{Conversion Factors}

SI to Inch/Pound

\begin{tabular}{lll}
\hline \multicolumn{1}{c}{ Multiply } & By & To obtain \\
\hline millimeter $(\mathrm{mm})$ & Length & \\
kilometer $(\mathrm{km})$ & 0.03937 & inch (in.) \\
meter $(\mathrm{m})$ & 0.6214 & mile (mi) \\
\hline & 1.094 & yard (yd) \\
\hline square meter $\left(\mathrm{m}^{2}\right)$ & Area & \\
square kilometer $\left(\mathrm{km}^{2}\right)$ & 0.0002471 & acre \\
\hline & 0.3861 & square mile $\left(\mathrm{mi}^{2}\right)$ \\
\hline liter $(\mathrm{L})$ & Volume & \\
cubic centimeter $\left(\mathrm{cm}^{3}\right)$ & 1.057 & quart (qt) \\
cubic kilometer $\left(\mathrm{km}^{3}\right)$ & 0.06102 & cubic inch (in $\left.{ }^{3}\right)$ \\
\hline & 0.2399 & cubic mile (mi $\left.{ }^{3}\right)$ \\
\hline gram $(\mathrm{g})$ & Mass & \\
metric ton & 0.03527 & ounce, avoirdupois (oz) \\
\hline
\end{tabular}

Temperature in degrees Celsius $\left({ }^{\circ} \mathrm{C}\right)$ may be converted to degrees Fahrenheit $\left({ }^{\circ} \mathrm{F}\right)$ as follows: ${ }^{\circ} \mathrm{F}=\left(1.8 \times{ }^{\circ} \mathrm{C}\right)+32$

\section{Abbreviations Used in This Report}

${ }^{\circ} \mathrm{C}$

$\mu \mathrm{g} / \mathrm{L}$

$\mathrm{C} / \mathrm{km}$

$\mathrm{g} / \mathrm{cm}^{3}$

$\mathrm{mg} / \mathrm{L}$

Mt

$\mathrm{mW} / \mathrm{m}^{2}$

ppm

sedex

$\mathrm{W} / \mathrm{m}^{\circ} \mathrm{C}$

BSR

MVT

$\mathrm{S} / \mathrm{C}$

TDS

TOC

TSR degree Celsius

microgram per liter

degree Celsius per kilometer

gram per cubic centimeter

milligram per liter

metric ton

megawatt per square meter

part per million

sedimentary exhalative

watt per meter per degree Celsius

bacterial sulfate reduction

Mississippi Valley type

sulfur/carbon

total dissolved solids

total organic carbon

thermochemical sulfate reduction 


\title{
Geologic Criteria for the Assessment of Sedimentary Exhalative (Sedex) Zn-Pb-Ag Deposits
}

\author{
By Poul Emsbo
}

\section{Introduction}

Sedex deposits account for more than 50 percent of the world's zinc $(\mathrm{Zn})$ and lead $(\mathrm{Pb})$ reserves (Tikkanen, 1986) and furnish more than 25 percent of the world's production of these two metals (Goodfellow and Lydon, 2007). More than 129 deposits of this type have been recognized in sedimentary basins around the world (Leach and others, 2005b; Goodfellow and Lydon, 2007). A compilation by Sangster and Hillary (2000) shows that the largest 65 deposits occur in 25 sedimentary basins, 6 of which contain more than 10 metric tons (Mt) combined $\mathrm{Pb}+\mathrm{Zn}$ (fig. 1). In order of decreasing endowment these are Mt. Isa-McArthur basins (7 deposits totaling $112 \mathrm{Mt}$ of $\mathrm{Zn}+\mathrm{Pb}$ metal), Selwyn basin (17 deposits totaling $55 \mathrm{Mt}$ ), Brooks Range (3 deposits totaling $40 \mathrm{Mt}$ ), Rajasthan (5 deposits totaling $20 \mathrm{Mt}$ ), Belt-Purcell (1 deposit totaling $19 \mathrm{Mt}$ ), and the Rhenish Basin (2 deposits totaling $11 \mathrm{Mt}$ ).

The published literature contains several thorough reviews of descriptive information, data, and conceptual or genetic models as well as geoenvironmental assessments of sedimentary-exhalative (sedex) deposits (Kelley and others, 1995; Lydon, 1995; Leach and others, 2005b; Goodfellow and Lydon, 2007). This report draws on previous syntheses, as well as on topical studies of sedex deposits, to determine the critical descriptive and genetic criteria that define sedex-type deposits. Also utilized in this analysis are studies of the tectonic, sedimentary, and fluid evolution of modern and ancient sedimentary basins. The focus here is on geologic characteristics of the six sedex-deposit-hosting basins containing greater than $10 \mathrm{Mt} \mathrm{Zn}+\mathrm{Pb}$. The enormous size of sedex deposits strongly suggests that basinscale geologic processes are involved in their formation. It follows that mass balance constraints can form a conceptual underpinning for the evaluation of potential mechanisms and the identification of geologic indicators of ore-forming processes in sedimentary basins.

The objective of this report is to use both descriptive information and conceptual models to identify processes critical to the formation of sedex deposits. The framework of the resulting ore deposit model is built on a "mineral systems approach" (Kreuzer and others, 2008). The mineral system schemes put forward by various authors have differed somewhat, but critical elements of hydrothermal ore-forming processes can be reduced to (1) source of fluids, (2) source of ore-transporting ligands, (3) source of metals, (4) drivers of fluid movement, (5) plumbing system or pathways, (6) physical and chemical traps for metal, and (7) outflow zones for discharge of spent hydrothermal fluids. Empirical data and genetic understanding of the physicochemical, geologic, and mass balance conditions necessary for each of these components required for ore formation will be used to establish a hierarchy of quantifiable geologic criteria that may be used in the upcoming U.S. Geological Survey National Assessments for sedex $\mathrm{Zn}-\mathrm{Pb}$-silver (Ag) deposits (Johnson and others, 2008). 


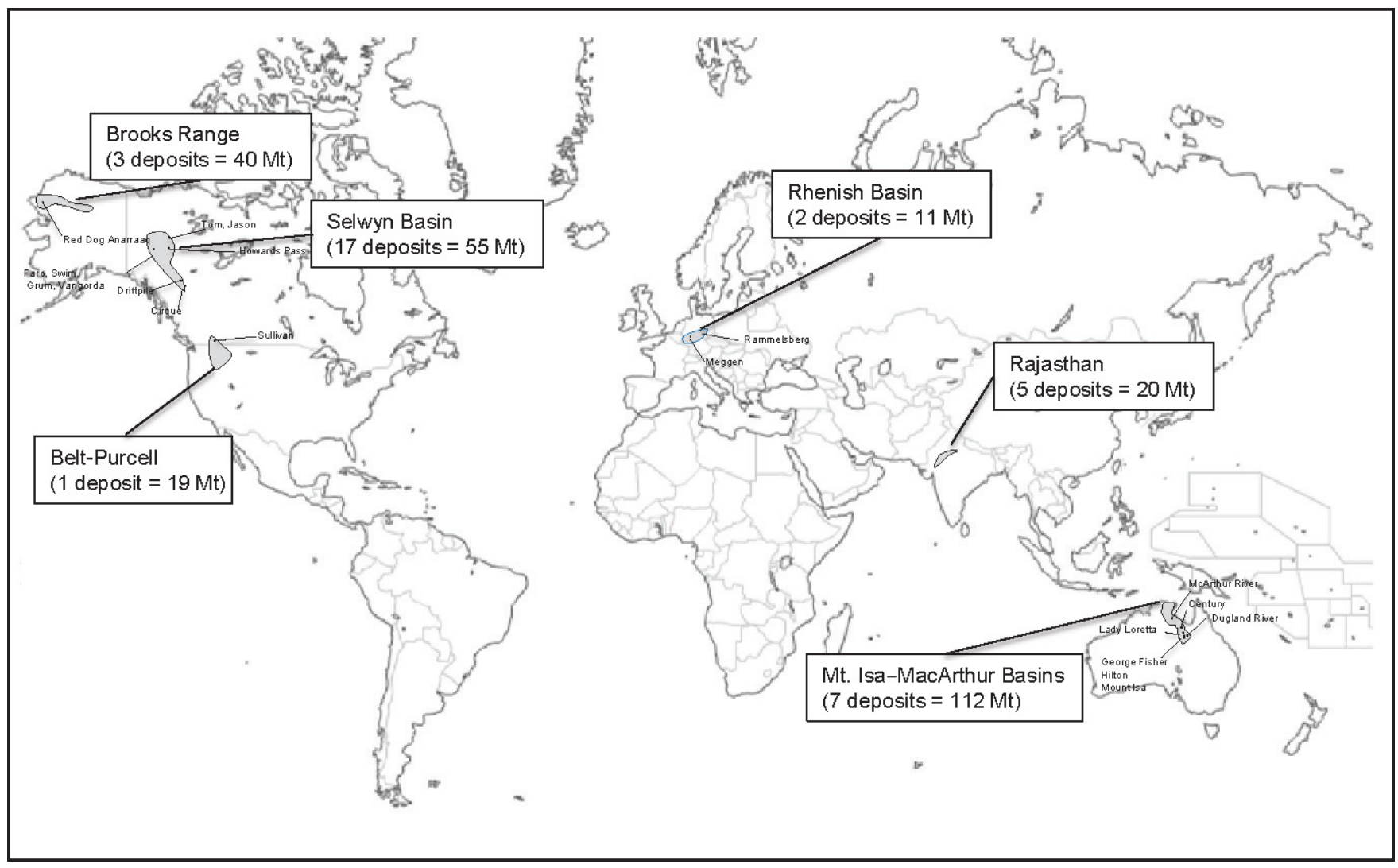

Figure 1. Six sedimentary basins that are known to contain a total endowment of more than $10 \mathrm{Mt}$ tons $\mathrm{Zn}+\mathrm{Pb}$ metal (in gray).

\section{Deposit Summary}

The term sedex, derived from sedimentary exhalative (Carne and Cathro, 1982), is based on the interpretation that the finely laminated or bedded sulfide ores that characterize this deposit type represent chemical sediments precipitated from hydrothermal fluids exhaled onto the sea floor. The use of genetic criteria to define a deposit type has caused considerable debate (Leach and others, 2005b), leaving some workers to prefer purely descriptive names such as shale-hosted $\mathrm{Pb}-\mathrm{Zn}$-Ag deposits or sediment-hosted stratiform $\mathrm{Zn}-\mathrm{Pb}-\mathrm{Ag}$ deposits. According to the original definition of Carne and Cathro (1982), sedex deposits have "bedded or laminated, tabular sulfide-rich bodies in carbonaceous shales or other, fine-grained clastic rocks." The sedex-deposit class has been substantially broadened by subsequent workers to include several genetically or geologically related deposit types. The model set forth in this report adheres to the original definition of sedex deposits because these variants, although formed by parallel genetic processes, are sufficiently different to require their own models.

$\mathrm{Sedex} \mathrm{Pb}-\mathrm{Zn}-\mathrm{Ag}$ deposits are hosted in marine sedimentary rocks within intracratonic or epicratonic rift basins. Deposits occur in carbonaceous shales in basin sag-phase carbonate rock, shale, or siltstone facies mosaics that were deposited on thick sequences of rift-fill conglomerates, red beds, sandstones or siltstones, and mafic or felsic volcanic rocks. The deposits show little spatial, temporal, or genetic association with igneous rocks. Ore bodies are generally tabular or stratiform and are localized in smaller fault-controlled subbasins near the margins of major depocenters. Laminated or bedded sulfide ores that are hosted in carbonaceous and pyritic, fine-grained shales and siltstones define this deposit type. The principal ore minerals, sphalerite and galena, are thought to have precipitated on or 
just below the sea floor from warm $\left(\sim 100^{\circ}\right.$ to $200^{\circ}$ Celsius $(\mathrm{C})$, saline (10 to 30 percent total dissolved solids) basin brines that ascended along basin-controlling synsedimentary faults. Deposition and sequestration of metals occurred by precipitation of sulfide minerals as a result of mixing of metaltransporting brine and locally derived $\mathrm{H}_{2} \mathrm{~S}$ produced by bacterial (and perhaps thermochemical) reduction of local seawater sulfate.

\section{Regional Geologic and Tectonic Environment}

Sedex $\mathrm{Zn}-\mathrm{Pb}$-Ag deposits occur in rift-generated sedimentary basins (Lydon, 1995; Leach and others, 2005b; Goodfellow and Lydon, 2007). Although rifting can occur in other tectonic regimes, such as intracratonic failed rift systems (Mt. Isa-McArthur Basins, perhaps the Belt-Purcell), epicratonic rifted passive margins (Selwyn Basin, Brooks Range), and distal back-arcs (Rhenish Basin), sedex basins share a common architecture.

The analysis of sedex-deposit-hosting sedimentary basins by Large $(1980,1983)$ established a relationship between sedex deposits and basin architecture. This relationship, which has been verified by a host of subsequent studies (Large, 1980; Lydon, 1995; Kelley and others, 2004; Large and others, 2005; Leach and others, 2005b; Goodfellow and Lydon, 2007), consists of the fact that sedex deposits occur in extensional fault-bounded, first-order epicontinental and intracratonic basins with dimensions in excess of 100 kilometers $(\mathrm{km})$. Within first-order basins, structurally controlled second-order basins occur at a scale of tens of kilometers and are controlled by half-graben structures. Second-order structures are characterized by abrupt changes in sedimentary facies and isopachs and by the occurrence of intraformational debris flows and breccias. The faults served as fluid conduits that focused hydrothermal brines from underlying strata onto the sea floor to form the deposits. Third-order basins, on the scale of a few kilometers, represent bathymetric lows that are euxinic, low-energy depositional environments dominated by organic-rich, pyritic, fine-grained shale and mudstone. Third-order basins provide ideal bathymetric and chemical environments for dense, bottom-hugging, metalliferous brines to accumulate and react with locally derived $\mathrm{H}_{2} \mathrm{~S}$ to form sulfide minerals that compose the ore.

The stratigraphic evolution of sedex-deposit-hosting rift basins can be divided into two phases. The rift phase is characterized by a $4-$ to $15-\mathrm{km}$-thick accumulation of coarse continental clastic sediments (conglomerates, red beds, sandstones, and turbidities) with, in many cases, subordinate riftrelated volcanic successions. Thermal subsidence of basin margins, a natural consequence of late-stage continental rifting, causes a landward migration of basin margins and the deposition of sag-phase shallow platform sediments (Einsele, 2000). The sag-phase shallow water carbonate rocks and finegrained shales and siltstones eventually transgress and cover basin rift-fill depocenters. With the exception of the Sullivan deposit in Canada, sedex deposits are hosted in 1- to 4-km-thick sequences of shallow water fine-grained sag-phase sediments.

\section{Theory of Deposit Formation}

\section{Source of Fluids Involved in Ore Component Transport}

The supposition that sedex deposits were formed by saline basinal brines derived from their host basin was a critical advance in formulating a theory for sedex deposit genesis (Hutchinson, 1980; Badham, 1981; Lydon, 1983). Although direct study of sedex ore fluids has been limited, a few robust fluid-inclusion studies have verified that sedex deposits form from $100^{\circ}$ to $200^{\circ} \mathrm{C}$ brines with salinities between 10-30 weight percent total dissolved solids (TDS) (Gardner and Hutcheon, 1985; Ansdell and others, 1989; Bresser, 1992; Leach and others, 2004; Polito and others, 2006). Despite the importance to the genesis of sedex deposits, the source or sources of dissolved salt (and water) in ore-forming brines is 
not well understood. Historically, direct dissolution of evaporites in the flow path of meteoric/marine waters has been the preferred source for dissolved salts (Goodfellow and others, 1993; Lydon, 1995). Although evaporites commonly form early in rift-sequences, a shortcoming of the salt-from-evaporite hypothesis, as highlighted by Lydon (2004), is that evaporites have not been reported in the rift sequences of any sedimentary basins hosting sedex deposits. Other proposed sources of salt are connate fluids trapped in sediments during burial (Lydon, 1995; Garven and others, 2001; Yang and others, 2004; Large and others, 2005; Yang and others, 2006) and the gravitational influx of residual brines, generated by the evaporation of seawater, on platforms coeval with deposition of sedex-deposit host rocks (Davidson, 1998; Leach and others, 2004; Lydon, 2004). Well-reasoned estimates suggest that thousands of cubic kilometers of brine are required to form large sedex deposits or districts (Goodfellow and others, 1993; Garven and others, 2001; Cathles and Adams, 2005). Irrespective of brine source, basin-scale processes are required to produce this extraordinarily large brine volume. Thus, constraining potential brine sources within a basin may allow effective assessment of its potential to host sedex deposits.

Geochemical and stable and radiogenic isotopic studies of modern basin brines have identified two processes for generating high-salinity brines in sedimentary basins, both ultimately related to subaerial evaporation of seawater (Hanor, 1994). Major solutes in basinal brines are derived from either residual brine that infiltrated down into underlying sedimentary sequences during evaporation, or dissolution of evaporite minerals (primarily halite) in the subsurface. A third proposed mechanism, membrane filtration, has not been demonstrated in natural environments and is untenable for large-scale production of highly saline brines (Hanor, 1994). The ratios of solutes discriminate between the two probable brine sources in modern basinal brines (Rittenhouse, 1967; Carpenter, 1978). Both end members, as well as their mixtures, are recognized in modern sedimentary basins, but the primary source of salt in most basins, even those filled with salt, is residual brine (Carpenter, 1978; Kharaka and others, 1987; Walter and others, 1990; Moldovanyi and Walter, 1992; Hanor, 1994, 1996).

New fluid inclusion solute data from six sedex deposits (Century, McArthur River, Sullivan, Red Dog, Watson's Load, Silver King) demonstrate that ores contain residual brine derived from the evaporation of seawater. $\mathrm{The} \mathrm{Cl} / \mathrm{Br}$ and $\mathrm{Na} / \mathrm{Br}$ mole ratios from all six deposits plot on or close to the seawater evaporation line. The data imply that the primary salinity source for fluids that formed the sedex deposits was evaporatively concentrated seawater. Moreover, the data plot in the center of the relatively small compositional field for Mississippi Valley-type (MVT) basinal brines, which suggests that they share a common origin. It is significant that nearly all of the $\mathrm{Cl} / \mathrm{Br}$ values are below the value for modern seawater of 670 and range down to 220, which indicates that the brines formed from seawater near halite saturation. The similarity between fluid compositions of sedex and MVT deposits confirms previous hypotheses that the two ore types formed from fluids of similar origins. Because neither deposit type provides evidence for halite dissolution as a primary source for the parent fluid, residual brines are considered fundamental to the genesis of all basin-hosted $\mathrm{Zn}-\mathrm{Pb}$-Ag deposits.

It has been demonstrated that evaporation of large volumes of seawater to salt saturation requires specific conditions, including highly restricted circulation in shallow platform environments caused by barriers such as sills or reefs that allows evaporation to exceed the influx of fresh seawater; and paleolatitude positions of $25^{\circ} \pm 10^{\circ}$ characterized by hot arid climates in which evaporation exceeds precipitation (Warren, 2006). A striking feature of sedex basins is that they are rimmed by unusually large $\left(10^{5}\right.$ and $10^{6}$ square kilometers $\left.\left(\mathrm{km}^{2}\right)\right)$ shallow-water epeiric carbonate platforms that represent ideal sedimentary environments for brine generation. Evidence for evaporative environments in marginal basin sag-sequences has been noted in several basins (Davidson, 1998; Leach and others, 2004; Lydon, 2004; Goodfellow and Lydon, 2007) and paleolatitude reconstructions indicate that sedex basins were in latitudes conducive to evaporation during their sag-phase (Goodfellow and others, 1993; 
Leach and others, 2005a). Among the six major sedex basins considered in this analysis (fig. 1), all have evaporative platform sequences with evaporite minerals (mainly anhydride and some halite), breccias formed by salt dissolution or escape, or regional dolomitization. Moreover, as described below, the timing of evaporation correlates in time with ore formation.

\section{Deduced Geologic Assessment Criteria}

- The study of sedex basins combined with new fluid-inclusion data show that sedex deposits form from residual brines generated by seawater evaporation. Because of the large platform areas needed to produce the volumes of brine required to form sedex deposits, evaporative sediments should be recorded in the platform sedimentary record at or below prospective stratigraphic intervals. Indicators include evaporite minerals (anhydrite, some halite), breccias indicating salt dissolution or escape, and regional dolomitized platform. These indicators are observable in all six sedex-deposithosting basins evaluated here.

- Paleolatitude reconstruction of basins is an efficient method for determining if a basin is likely to have experienced seawater evaporation during its history, and such reconstruction may provide an effective method for screening prospective basins for sedex deposits.

- The absence of salt dissolution in fluid that formed sedex deposits combined with lack of evaporites in the rift sequences of sedex-deposit-hosting basins suggests that evaporites in the fluid flow path are not essential to the formation of sedex deposits.

\section{Sources of Ligands and Chemical Transport and Transfer Processes Involved in Ore Component Transport}

During the past 30 years, sedex deposit research, in tandem with geochemical studies of modern brines and geochemical modeling, has provided insights into the source, transport, and deposition of metals in sedimentary basins. The studies constrain the temperature, salinity, $\mathrm{pH}$, and chemical conditions necessary to transport $\mathrm{Pb}, \mathrm{Zn}$, and $\mathrm{Ag}$ in basin brines. The fluid inclusion data, mineral assemblages, and isotopic data that are available indicate the deposits formed at $100^{\circ}$ to $200^{\circ} \mathrm{C}$ from fluids with neutral to moderately acidic $\mathrm{pH}$ and salinities that range from 10 to 30 percent TDS. Additional insights on the brines can be obtained from comparisons with modern-day brines, from fluid inclusion data from MVT deposits, and from thermodynamic modeling.

There is a general consensus that ore metals are transported dominantly as chloride complexes, and thus salinity (chlorinity) is a primary control on their solubilities. Empirical and thermodynamic evidence suggests that saline brine (less than about 15 percent TDS) is necessary to form a sedex deposit. A compilation of chemical analyses of modern metal-rich brines (Hanor, 1996) shows that chlorinity of about $10^{5} \mathrm{mg} / \mathrm{L}$ (17 weight percent TDS) is a threshold below which $\mathrm{Zn}$ concentrations are $<1 \mathrm{ppm}$ - far below what is believed necessary to form an sedex deposit (Hanor, 1996).

Similarly, fluid temperatures obtained from sedex fluid inclusions are $>100^{\circ} \mathrm{C}$; chemical modeling of metal solubility indicates that $100^{\circ} \mathrm{C}$ is the minimum temperature for moving ore-forming quantities of $\mathrm{Pb}$ and $\mathrm{Zn}$ (Cooke and others, 2000; Emsbo, 2000). On the basis of this constraint, Southgate and others (2006) have proposed the concept of a "thermal leaching window" as a temperature interval of burial $\left(\approx 150-250^{\circ} \mathrm{C}\right.$ at normal geothermal gradients) through which a stratigraphic package of metal source rock can be efficiently leached, liberating metals to a deep basin brine. Temperature gradients of $20^{\circ}$ to $25^{\circ} \mathrm{C}$ are common in sedimentary basins, and $30^{\circ} \mathrm{C} / \mathrm{km}$ is commonly assumed as the upper limit in models of various processes in sedimentary basins (Raffensperger and Vlassopoulos, 1999; Lin and others, 2000; Armstrong, 2005). Theoretically, surface

heat flow in continental regions is typically 50 to 65 megawatts/square meter $\left(\mathrm{mW} / \mathrm{m}^{2}\right)$, the global mean 
continental surface heat flow being $57 \mathrm{~mW} / \mathrm{m}^{2}$ (Turcotte and Schubert, 1982). Owing to lower-thanaverage heat production in sedimentary rocks, basal heat flows in sedimentary basins should span a similar range, except in active rift basins where basal heat flows may reach $90 \mathrm{~mW} / \mathrm{m}^{2}$. Sedimentary rocks typically have thermal conductivities of 1.5 to 2.5 watts $/ \mathrm{meter} / \mathrm{Celsius}$ degree $\left(\mathrm{W} / \mathrm{m}^{\circ} \mathrm{C}\right)$ (Clauser and Huenges, 1995). If we assume a high basal heat flow of $60 \mathrm{~mW} / \mathrm{m}^{2}$, no internal heat production, and a thermal conductivity of $2 \mathrm{~W} / \mathrm{m}^{\circ} \mathrm{C}$, then a temperature gradient of $30^{\circ} \mathrm{C} / \mathrm{km}$ during the sag phase of a sedimentary basin is possible. With a typical mean annual surface temperature of $15^{\circ} \mathrm{C}$, this thermal gradient will result in a temperature of $105^{\circ} \mathrm{C}$ at a depth of $3 \mathrm{~km}$. Thus $3 \mathrm{~km}$ is a conservative estimate of the total sediment thickness required to form a sedex deposit. This conclusion is supported by the fact that ores in the six most important sedex basins (fig. 1) occur in stratigraphic intervals overlying at least $5 \mathrm{~km}$ of sediment fill somewhere in the basin.

Analysis of modern brines and chemical modeling have demonstrated that, although variables like temperature and $\mathrm{pH}$ are important, high $\mathrm{Zn}$ and $\mathrm{Pb}$ solubilities in brines above $100^{\circ} \mathrm{C}$ result primarily from a combination of high salinity and low $\mathrm{H}_{2} \mathrm{~S}$ concentration (Kharaka and others, 1987; Moldovanyi and Walter, 1992; Hanor, 1996). Chemical analysis of modern brines and thermodynamically calculated solubilities of base metals show an inverse relationship to $\mathrm{H}_{2} \mathrm{~S}$ contents, and $\mathrm{Zn}$ and $\mathrm{Pb}$ concentrations in brines decrease by several orders of magnitude in the presence of even moderate contents of $\mathrm{H}_{2} \mathrm{~S}$ (Kharaka and others, 1987; Moldovanyi and Walter, 1992; Hanor, 1996; Cooke and others, 2000; Emsbo, 2000). The solubility of Ba is also controlled by salinity, temperature, and $\mathrm{pH}$, but its dominant control in basin brines is the concentration of $\mathrm{SO}_{4}$, as Ba solubilities are extremely low in the presence of sulfate. Various proportions of base metals, barite, and gold led Emsbo (2000) to classify sedex deposits into very large $\mathrm{Pb}-\mathrm{Zn}-\mathrm{Ag}$ deposits, intermediate-size $\mathrm{Pb}-\mathrm{Zn}-\mathrm{Ag}-\mathrm{Ba} \pm \mathrm{Au}$ deposits, and deposits of low base metal and high barite with or without Au. This spectrum is believed to reflect the concentration and redox state of sulfur in the brine, which is ultimately controlled by the lithology and redox buffering capacity of basin-fill sediments.

Because of its dominant control on metal solubility, the $\mathrm{H}_{2} \mathrm{~S}$ concentration is an important parameter in basinal processes. At depth, hydrogen sulfide is generated in sedimentary basins by thermochemical sulfate reduction (TSR) as well as by thermal decomposition of kerogen, coal, and high-sulfur oils (Hunt, 1996). It is significant that all of these processes involve organic carbon, which is consistent with observations that indicate that the amount of $\mathrm{H}_{2} \mathrm{~S}$ in deep drill holes correlates with the content of organic matter in surrounding rocks (Le Tran, 1972). In addition to the generation of $\mathrm{H}_{2} \mathrm{~S}$, a fundamental control on $\mathrm{H}_{2} \mathrm{~S}$ concentration in sedimentary brines is its removal by reaction with $\mathrm{Fe}$ to form pyrite. The highest $\mathrm{H}_{2} \mathrm{~S}$ concentrations observed in sedimentary basins are in rocks with low contents of reactive $\mathrm{Fe}$ - for example, carbonate rocks (Hunt, 1996). Thus, the amount of $\mathrm{H}_{2} \mathrm{~S}$ generated at deeper levels in a sedimentary basin is ultimately controlled by the rate of its production through TSR, balanced by the extent of its removal through the sulfidation of reactive Fe. Many workers have stressed the importance of oxidized rift-fill continental clastic rocks (for example, red beds) as a source of metals in sedex deposits. The synthesis carried out for this report confirms that sedex basin rift-fill sequences are dominated by fluvial-deltaic and shallow marine continental clastic sequences composed of red beds, sandstones, conglomerates, and siltstones. These sequences, which are low in organic carbon and high in reactive iron, are ideal for buffering saline brines to compositions favorable for the transport of $\mathrm{Zn}, \mathrm{Pb}$, and $\mathrm{Ag}$. 


\section{Deduced Geologic Assessment Criteria}

- Empirical and thermodynamic evidence suggests saline brine (more than about 17 percent TDS) is necessary to form a sedex deposit. Thus, geologic evidence of environments capable of generating saline brines is required for a basin to be permissive for sedex mineralization.

- Fluid temperatures of at least $100^{\circ} \mathrm{C}$ are required to form sedex deposits. Thermal regimes of sedimentary basins require that at least $3 \mathrm{~km}$ of sediment fill is required to produce these temperatures. Thus at least $3 \mathrm{~km}$ of sediment fill above crystalline basement is required for a basin to be prospective for $\mathrm{Zn}-\mathrm{Pb}-\mathrm{Ag}$ deposits. Moreover, within deeper basins, only stratigraphic horizons overlying more than $3 \mathrm{~km}$ are prospective.

- Oxidized syn-rift sediments are ideal rocks to buffer ore fluids to compositions necessary for metal scavenging and transport because of their low organic and high reactive Fe contents.

- Various proportions of base metals, barite, and gold in mineral occurrences may ultimately reflect the lithology and redox buffering capacity of basin-fill sediments in the metal source regions, and thus they provide information about metal endowment and prospectivity of sedimentary basins.

\section{Sources of Metals and Other Ore Components}

The radiogenic and stable isotopic compositions of sedex ores constrain the source or sources of ore components. Many studies have demonstrated that $\mathrm{Pb}$ and $\mathrm{Sr}$ originate in the continentally derived clastic sediments in host basins (Ayuso and others, 2004; Emsbo and Johnson, 2004; Large and others, 2005; Leach and others, 2005b). Moreover, fluid-flow and chemical arguments (see above) further suggest that oxidized, coarse clastic sediments (such as red beds, conglomerates, sandstones) in underlying rift-fill sequences are the most likely source of ore metals.

The vast mass of metal that has been emplaced in and around sedex deposits require quantities of source rock that should be recognizable on a basin scale. For example, supergiant sedex deposits can contain greater than $20 \mathrm{Mt}$ of $\mathrm{Zn}$ metal. This amount of metal does not include lower grade, uneconomic mineralization marginal to a deposit, which is likely to contain a metal mass 10 times greater than the ore reserve (Cathles and Adams, 2005). For example, lowering the cutoff grade (of 7 percent $\mathrm{Zn}+\mathrm{Pb}$ ) of the Tom deposit, Canada, by 1 percent increases the mass of ore fivefold (Goodfellow and others, 1993). Thus a conservative estimate for the total amount of $\mathrm{Zn}$ exhaled by a world-class sedex system would be $>200 \mathrm{Mt}$. A study by Zielinski and others (1983) of continental red beds like those proposed as source rock for sedex deposits showed an average $\mathrm{Zn}$ content of $\sim 70 \mathrm{ppm}$. Leaching tests on red beds suggest that 22 percent of the $\mathrm{Zn}(\sim 15 \mathrm{ppm})$ is extractable under conditions expected for a metal transporting solution (Zielinski and others, 1983). At a typical sandstone bulk density of $2.2 \mathrm{~g} / \mathrm{cm}^{3}$, more than 6,000 cubic kilometers $\left(\mathrm{km}^{3}\right)$ of continental red beds are required, if we assume 100 percent efficient leaching, transport, and precipitation of $\mathrm{Zn}$ at the site ore formation, to furnish the metal for a world-class sedex deposit.

By total mass, sulfur is the most enriched element in sedex deposits. Isotopic studies have demonstrated that sulfur originates from marine sulfate, which is reduced to sulfide by bacterial or thermogenic reduction. It is unlikely that lacustrine water, which is typically two orders of magnitude lower in sulfate, would be able to supply sufficient sulfate to sequester the metal in a major sedex deposit. While it been proposed that some sedex deposits formed in lacustrine environments (see the discussion in Goodfellow and others, 1993), this interpretation is inconsistent with marine sulfur isotope signatures and is not backed by paleontologic or sedimentologic evidence. The requirement of reduced sulfur derived from marine sulfate may also have secular importance. For example, the absence of Archean sedex deposits may be a consequence of a low-sulfate ocean inferred for Archean time (Leach and others, 2005a; Lyons and others, 2006; Goodfellow and Lydon, 2007). It has also been suggested 
that a correspondence between sedex deposits and global anoxic events may reflect periods when reducing conditions favored sulfide generation and efficient precipitation and preservation of metal sulfides (Turner, 1992).

\section{Deduced Geologic Assessment Criteria}

- Mass balance considerations suggest that thousands of cubic kilometers of rift-fill coarse clastic sediments are required to supply the amount of metal in a major sedex deposit. This observation suggests that the volume of rift-fill sequences should be recognizable on the basin scale for a basin to be prospective. Moreover, the volume of available source rock within a basin may place a limit on the maximum amount of metal that can be extracted and fixed in sedex deposits.

- Seawater may be required to supply sulfur for a sedex deposit. If so, evidence of marine conditions should be evident in the stratigraphic intervals that host sedex deposits.

- The requirement of marine sulfate as a source of reduced sulfur may limit sedex deposit formation to Proterozoic and Phanerozoic time. The correspondence of Sedex deposits with regional, and perhaps global, anoxic events may identify periods of time that are favorable for formation of sedex deposits.

\section{Fluid Drive, Including Thermal, Pressure, and Geodynamic Mechanisms}

There is little agreement as to the hydrologic processes, including sources of energy, heat transport and transfer processes, and geodynamic processes that drive sedex-deposit-forming hydrothermal systems. Proposed models can be classified into three general types, which are briefly summarized and evaluated below. Because of identified difficulties of previous models and its potential importance for the assessment for sedex deposits, a new fluid-flow model is proposed that incorporates new fluid inclusion data, results of basin analysis, and constraints from previous fluid-flow models.

\section{Sedimentary Compaction Model}

Several previous models for the formation of sedex deposits proposed that fluids were driven and discharged to the sea floor by sediment accumulation and compaction (Lydon, 1983; Sawkins, 1984; Lydon, 1986). The basin architecture highlighted by the stratal aquifer model of Lydon (1983, 1986) forms the conceptual underpinning for several sedimentary compaction fluid-flow models as well as for thermal convection models. Fundamental to the sedimentary compaction model are 2-3-km-thick successions composed of low-permeability, fine-grained, sag-phase sediments that overlie permeable, syn-rift clastic rocks. The low-permeability cover is believed to act as an aquitard, attenuating flow and promoting the development of an overpressured brine reservoir in underlying permeable clastic reservoirs. Breaching of the cover sequence by extensional faulting is thought to initiate fluid discharge, which continues as the sediment column compacts with declining fluid pressure. This model accords with the general architecture of sedex-hosting basins, the occurrence of deposits in sag-phase sediments, and the localization of deposits along extensional faults that were active during mineralization. However, hydrologic modeling suggests that sedimentation and compaction rates in sedimentary basins are inadequate to drive the vast quantity of fluids required to form sedex deposits (Bethke, 1985; Neuzil, 1995). The "squeeze" model of Garven and others (2001) that proposed both compaction and pressure-driven fluid flow in a transpressional regime demonstrated that, although possible, a sedimentary compaction mechanism is still unlikely to provide the drive required to form sedex deposits. 
Multiple periods of sedex mineralization throughout the same depocenter, which is a characteristic of most sedex basins, is also difficult to explain with this model. Compaction-driven models would require basin-wide equilibration of fluid pressures and full compaction of the sedimentary column to produce the volume and flow of brines needed to form a substantial sedex deposit. Thus, breaching of an over-pressured reservoir and subsequent compaction and squeezing of the sedimentary column because of irreversible loss of porosity and permeability, should be a one-time event within a basin.

\section{Free Convection Models}

Convective fluid flow is favored by many workers to account for the formation of sedex deposits (Russell and others, 1981; Goodfellow and others, 1993; Garven and others, 2001; Large and others, 2005). Garven and others' (2001) numerical models compare previously proposed fluid-flow models, including sediment compaction, free convection, and topographically driven flow on a geologically well-constrained finite element mesh through the southern McArthur Basin. They concluded that the most likely mechanism for the formation of the McArthur River deposit was free convection driven by density variations that resulted from normal geothermal gradients. They proposed a two-stage hydrologic model similar to the stratal aquifer model of Lydon $(1983,1986)$. In stage one, brines formed by halite dissolution or evaporation infuse underling clastic sediments during the rift phase of basin development. Burial of the rift-phase clastic sediments by low permeability sag-phase sediments is thought to have promoted the formation of an isolated brine reservoir, in which convection cells developed and persisted, because of tectonic stability, for about $70 \mathrm{~m}$.y. Long-lived convective circulation is thought to be crucial because it promotes scavenging of metals from the reservoir rocks and development of metal-rich brines. During the second stage of the model, rupture of the overlying aquitard by large, parallel, high-angle normal faults establishes a recharge-discharge convective cell that allows the hot, metal-rich reservoir brines to ascend a fault while being replaced by cold seawater descending along a sympathetic fault. Garven and others (2001) calculate that fluid zinc contents of $1,000 \mathrm{ppm}$ would be sufficient to transport the $20 \mathrm{Mt}$ of zinc contained in the McArthur River deposit in $<7$ m.y. The duration of 7 m.y., while plausible, is considered an upper bound for the duration of sedex hydrothermal systems. Using a more conservative estimate of $100 \mathrm{ppm} \mathrm{Zn}$ in solution would give an untenable 70 m.y. to form a world-class sedex deposit. Moreover, Yang and others (2004) coupled transient fluid flow, heat, and solute transport modeling on the same finite element mesh used by Garven and others (2001), and they thus demonstrated that the model results are very sensitive to specific fault and aquifer geometries and basin salinity structure. For example, the salinity structure observed in most modern basins, with the highest salinities in the bottom of the basin, would require unrealistic thermal gradients to maintain convection. Application of a convective fluid-flow model to the Red Dog deposit requires paleoheat flows of $150-160 \mathrm{~mW} / \mathrm{m}^{2}$ to drive hydrothermal convection (Garven and others, 2003). This heat flow is at least three times as high as the heat flows that have been measured in the sag-phase of modern basins and is about twice those in rift-phase basins (see above). No geologic evidence has been found to support paleoheat flows of this magnitude in sedex basins.

Another potential problem with the convective models is that, without recharge of new brine into the system, there is a potential problem with salt mass balance, particularly in basins with multiple mineralizing events. For example, the simulations by Yang and others (2004) show a depletion of the reservoir salinity to about 10 percent TDS after about 60,000 years. A drop in salinity to 10 percent would limit Zn solubility to $<1 \mathrm{ppm}$ (see previous section). Similarly, mass balance considerations suggest that, even assuming a fluid zinc concentration of $1,000 \mathrm{ppm}, 200 \mathrm{~km}^{3}$ of brine would be required to form a large sedex deposit which, if we assume about 10 percent porosity, corresponds with 
the entire model reservoir volume. Using more conservative $\mathrm{Zn}$ concentrations of 10 to $100 \mathrm{ppm}$ gives minimum brine volumes 10 to 100 times larger. The extraction of such a large mass of salt could potentially deplete the salinity of an entire basin. For example, an ore fluid with $100 \mathrm{ppm} \mathrm{Zn}$ would require the extraction of $2,000 \mathrm{~km}^{3}$ of brine. Its replacement by seawater ( 3.5 percent salt) would dilute $\mathrm{a} \pm 60,000-\mathrm{km}^{3}$ reservoir, with 10 percent porosity, below the 17 percent salinity threshold required to transport $\mathrm{Zn}$, making it difficult to make a later deposit in the basin. Overall, mass balance considerations suggest that multiple large sedex events in the same basin, as is characteristic of important sedex basins (fig. 1), would require replenishment of brine, a phenomenon that is unaccounted for in current convection flow models.

\section{Topographically Driven Flow Model}

Topographically driven flow models similar to those proposed for MVT and Irish-type deposits have been proposed for sedex deposits. However, there is little evidence of the regional-scale orogenic belts that would have provided the high elevation required to drive regional fluid flow at the time of sedex-ore formation (Goodfellow and others, 1993; Large and others, 2005). Garven and others (2001) determined that elevated basin margins established during rifting are unlikely to drive sufficient fluid flow. Moreover, sedex deposits form during thermal subsidence when basins are rimmed by large, lowrelief carbonate platforms that extend for hundreds of kilometers from the basin margin.

\section{Density-Driven Fluid Flow: A New Fluid-Flow Model}

As noted above, new fluid inclusion solute data suggest that sedex deposits are formed from residual brine that results from the evaporation of seawater. The general correspondence between the timing of mineralization and intense evaporation on platform margins, and the position of the important sedex basins in high-evaporative paleolatitudes, suggests a causative relationship.

The large shallow-water epeiric carbonate platform sequences $\left(>10^{5} \mathrm{~km}^{2}\right)$ rimming sedex basins have been shown to be deposited at latitudes conducive to high evaporation rates $\left(25^{\circ} \pm 10^{\circ}\right)$. Note that paleolatitude reconstructions of Phanerozoic sedex-hosting basins by Leach and others (2005a) have shown that about 85 percent of ores were deposited at such paleolatitudes. High-resolution stratigraphic, biostratigraphic, and geochronologic analysis of the six most fertile sedex basins reveals twelve mineralizing episodes corresponding exactly with discrete periods of intense evaporation of seawater on the platform. The temporal correspondence between mineralization and evaporite deposition suggests a causative relationship. Preliminary results from an ongoing U.S. Geological Survey project established to numerically model fluid flow in sedex basins suggests that dense residual brines generated by seawater evaporation will infiltrate basin margins and descend into deep, permeable, clastic reservoirs $>6 \mathrm{~km}$ thick. Brines flow laterally through such clastic sequences toward the basin depocenter until expelled to the sea floor by fault conduits in the distal basin. Calculated flow rates for density-driven simulations exceed those of other fluid-flow models when similar permeability values are assumed. An important aspect of this modeling is the influence that the permeability of rift-fill clastic sequences has on fluid flow. Slight reductions in the permeability of these sequences markedly decrease fluid flow to levels prohibitive for ore formation. Moreover, as demonstrated by the modeling of Jones and others (2002) of reflux brines in carbonate platforms, permeable faults along the platform margin will cause some fluid to convect upward into shallow sequences of the platform margin. This flow might explain the common small MVT-style deposits or higher temperature saddle dolomite that have been recognized in most carbonate platforms inboard and approximately coeval with the basin facies that host the deposits. 
The fluid inclusion solute data, the temporal correlation between ore formation and seawater evaporation, and the numerical modeling jointly suggest that density-driven fluid flow triggered by the evaporation of seawater is fundamental to sedex ore formation. The association between sedex deposits and sag-phase sediments may have less to do with the influence of an aquitard on basin fluid flow than with the development of a basin environment during the sag-phase characterized by large shallow-water epeiric carbonate platforms capable of generating large volumes of brine. It is interesting to note that the Belt Basin is unusual in that a large evaporative platform margin developed during the rift-phase. Thus, a density-driven model may explain the anomalous occurrence of the Sullivan deposit in rift-phase strata of the Basin.

\section{Deduced Geologic Assessment Criteria}

- The empirical and conceptual relationship of large evaporative shallow-water epeiric carbonate platforms and sedex deposits suggests this sedimentary environment is fundamental to sedex formation.

- A density-driven fluid flow-model, which is supported by the temporal correlation between ore formation and seawater evaporation on platform margins, overcomes many of the fluid flow and salt mass balance shortcomings of previously proposed fluid-flow models.

- The temporal correlation between ore formation and seawater evaporation suggests that distal stratigraphic intervals that are coeval with platform intervals that exhibit evidence for evaporative conditions (for example, evaporite minerals such as anhydrite and some halite, breccias indicating salt dissolution or escape, and regional dolomitization) should be viewed as highly prospective for sedex mineralization.

- The density-driven fluid-flow model suggests that paleolatitude reconstructions of sedimentary basins may be a useful parameter in identifying specific time intervals within basins that are prospective for sedex deposits.

- Fluid-flow modeling indicates that the permeability structure of rift-fill clastic sequences is critical to brine movement and sedex deposit formation.

- The occurrence of MVT-style mineralization and higher temperature dolomite along platform margins may be a strong indicator of the fluid-flow systems that form sedex deposits.

\section{Conduits or Pathways that Focus Ore-Forming Fluids}

It has been well established that sedex deposits are associated with long-lived regional structures that control the development of first- and second-order basins. Deposits and districts are typically oriented along second-order structures that control basin half-graben depositional centers. The longevity of these structures, which is apparent from their influence on basin configuration and sedimentary facies through time, is thought to reflect repeated reactivations of deep-rooted primary basement faults (Large and others, 2004; Emsbo and others, 2006). Most deposits show a direct relationship between active fault movement and ore formation. Fault movement is expressed as growth faults with rapid facies changes, periodic influx of coarse breccias and debris flows derived from fault-scarps, synsedimentary slumping, stratigraphic thickening toward subsiding basin margins, and foundering of basin environments. Interpreted rift-related structural regimes include normal extensional faults, orthogonal transform faults, and wrench faults with transpressional and transtensional segments (Emsbo and others, 1999; Large and others, 2004; Goodfellow and Lydon, 2007). Finally, the association of sedex deposits with post-ore thrust faults in tectonically disrupted strata reflects inversion of the basin by reverse movement on original normal faults (Emsbo and others, 2006). 
Fluid flow is indicated by Fe- and Mn- carbonate alteration, in some cases extensive silicification, and perhaps tourmalinization (such as at Rammelsberg, Sullivan, Tom and Jason, McArthur River, perhaps Red Dog) (Large and others, 1998; Kelley and others, 2004; Lydon, 2004; Goodfellow and Lydon, 2007). Regionally, this study shows that early diagenetic dolostone formation associated with descending or advecting brines derived from overlying evaporite sequences is universal in sedex basins. Moreover, porous clastic sediments in platform sequences and rift-fill sediments in the deeper sequences in the McArthur Basin have been shown to be regionally alkali metasomatized (Davidson, 1998).

An important consideration in sedex-ore genesis is the physical behavior of fluids at the seawater or sediment interface. Sangster (2002) separated sedex deposits into vent-proximal and vent-distal types on the basis of the presence or absence of discordant, feeder, vent or stringer zones below the stratiform ore. In the case of vent-proximal deposits and those with subsea floor replacement mineralization such as the Anarraaq deposit in Alaska (Kelley and others, 2004), the thickest accumulation of ore tends to be on the margin of feeder fault systems. In the case of the vent-distal deposits, metal accumulations are believed to be controlled by basin floor topography. Exhaled brines, because of their density, hug the bottom and seek paleobathymetric lows in which they accumulate as brine pools. While bottom-hugging brines have been demonstrated to travel great distances in modern basins (Sangster, 2002), it is believed that most sedex deposits in fault-controlled, restricted, third-order basins lie within a few kilometers of major fault systems. Third-order subbasins are generally recognized by their greater proportion of reduced facies that contain pyritic- and organic-rich sediments, increasing intrastratal thicknesses, and thickness variations and inferred flow directions of debris flows.

\section{Deduced Geologic Assessment Criteria}

- Areas within a few to tens of kilometers of large basin-bounding faults that control second-order features within sedimentary basins are highly favorable.

- Synsedimentary faulting as indicated by abrupt and truncated facies boundaries in platform-to-slope transition, thick debris flows, intraformational breccias, changes in isopach thicknesses, and synsedimentary slump structures are highly useful indicators of favorable stratigraphic horizons for ore.

- On a local scale, increasing intrastratal and debris flow thicknesses, and increasing organic matter and pyrite concentrations in reduced sediments, can all be used as vectors toward basin lows where brine may accumulate and form ore.

- Extensive dolomitization of platform carbonate rocks and alkali-altered platform and rift-phase clastic sediments are strong indicators of productive sedex basins.

- On a local scale, faults that were fluid conduits may be identified by wallrock alteration with Fe- and Mn-rich carbonate rocks or silicification, and perhaps tourmalinization.

\section{Nature of Traps and Wallrock Interaction that Trigger Ore Precipitation}

A unique attribute of sedex deposits is that ore metals are trapped by $\mathrm{H}_{2} \mathrm{~S}$ that is generated by bacteria in local sedimentary environments. Organic matter $\left(\mathrm{C}_{\text {org }}\right)$ is more abundant in sedex deposits than in typical shales and marls, with concentrations in the deposits commonly ranging from 3 to 10 weight percent (Turner, 1992; Goodfellow and others, 1993; Leach and others, 2005b). There is a general correspondence between the amount of organic matter and ore grades in many deposits. Organic matter is important in the genesis of sedex deposits because bacterial sulfate reduction (BSR), in which bacteria metabolize organic compounds, produces the sulfide that precipitates the ore metals. In addition, organic matter enrichments are a consequence of the enhanced preservation that characterizes anoxic depositional basins and of increased accumulation rates of organic matter relative to diluting terrigenous clastic sediments. 
Berner and Raiswell (1983) and Leventhal (1983) noted a linear correspondence between the amounts of organic matter and pyritic sulfur $\left(\mathrm{S}_{\text {metal }}\right)$ in normal marine sediments. Deviations from the linear relationship are common as a result of variations in the suitability of available organic matter for metabolism by sulfate-reducing organisms, the availability of sulfate, and the abundance of reactive metals to capture produced sulfide. Modern euxinic environments are notable for their higher $\mathrm{S} / \mathrm{C}_{\text {org }}$ ratios relative to typical marine sediments (Berner and Raiswell, 1983; Leventhal, 1983). The S/C ratios (Goodfellow and others, 1993) and the sulfur isotope systematics of sedex deposits are consistent with euxinic environments in which BSR was rapid relative to the supply of sulfate (Lyons and others, 2006; Johnson and others, 2009). These chemical and isotopic characteristics are expected in environments containing abundant organic carbon. Analyses of both normal and euxinic marine sediments demonstrate that greater than 1 weight percent $C_{\text {org }}$ is required to account for the high sulfur content of sedex deposits. The data of Berner and Raiswell (1983) and Leventhal (1983) show that sediment with less than 1 weight percent $C_{\text {org }}$ typically contains less than 0.5 weight percent $S_{\text {metal }}$ and thus limits the maximum amount of zinc that could be precipitated to $<1$ weight percent - considerably below what is economic for sedex deposits. Therefore, $\mathrm{C}_{\text {org }}$ contents $>1$ weight percent are considered an indicator of a favorable host rock.

Accumulations of $>1$ weight percent $\mathrm{C}_{\text {org }}$ in marine sediments can be explained by sustained bottom-water anoxia or unusually high rates of organic-matter production (Rollkotter, 2006). Basins with stratified water columns, such as those with hypersaline bottom water, are particularly suited to development of basal anoxic to euxinic water. A requirement for development of euxinic water is that the flux of $\mathrm{C}_{\text {org }}$ must be sufficient to deplete the supply of electron acceptors that are favored in preference to sulfate $\left(\mathrm{O}_{2}, \mathrm{NO}_{3}, \mathrm{MnO}_{2}\right.$, and $\left.\mathrm{Fe}_{2} \mathrm{O}_{3}\right)$. Depending on the physiography of the sea floor proximal to a forming sedex deposit, deposition and preservation of organic matter is likely to extend laterally from the deposit as carbonaceous sediments typified by black shales. This lateral accumulation is especially likely given the association of sedex deposits with global anoxic events (Goodfellow and others, 1993).

Achieving high concentrations of $\mathrm{C}_{\text {org }}$ also has implications for the sedimentological characteristics of the depositional environment. Anoxia enhances $\mathrm{C}_{\text {org }}$ preservation, but the flux of diluting clastic and chemical components of the sediment must also be limited to achieve high $\mathrm{C}_{\text {org }}$ contents. Rapid sedimentation would result in dilution of both organic matter and sedex metals such that economic accumulations would be unlikely. Therefore, depositional third-order basins that are distal from eroding landmasses are more likely to have sedex deposits with economic ore grades.

\section{Deduced Geologic Assessment Criteria}

- High contents of $\mathrm{C}_{\text {org }}$ are essential for the production of sulfide, which is necessary for precipitation of sedex ore metals; it and therefore is a useful guide in the evaluation of the suitability of a potential host rock.

- Regional or global anoxic events may be favorable time periods for mineralization.

\section{Structure and Composition of Residual Fluid Outflow Zones}

Sedex deposits are unique in that their ore fluids are vented into hydrologically restricted basins. Dispersion halos and zoning of the ore metals $\mathrm{Fe}, \mathrm{Ba}$, and $\mathrm{Si}$ are observed at distances of tens and even hundreds of kilometers from deposits (Goodfellow and others, 1993; Lydon, 1995; Large and others, 1996; Large and McGoldrick, 1998; Large and others, 2005; Goodfellow and Lydon, 2007). Moreover, the presence of basin-wide organic-rich metalliferous black shales and $\mathrm{PO}_{4}, \mathrm{Fe}$, and $\mathrm{Mn}$ deposits in mineralized horizons has been noted (Turner, 1992; Large and others, 1998; Emsbo, 2004; Emsbo and 
others, 2005; Goodfellow and Lydon, 2007) and, in fact, some or all of these have been recognized by this study in all of the basins evaluated.

The interrelationships between diverse deposit types are poorly understood. Traditionally, the basin-wide phenomena have been explained by upwelling of cold, nutrient-rich, ocean waters onto the continental shelf. The increased nutrients in shallow marine environments are thought to cause, as observed along modern upwelling coastlines, a surge in bioproductivity and corresponding eutrophication, anoxic or dysoxic conditions, and sequestration of organic carbon. In this model, metal and phosphate in the shale are derived from seawater and accumulated through a variety of biogenic and chemical mechanisms. Alternatively, Emsbo and others (2005) proposed that hydrothermal basinal fluids may have been the source of nutrients. Brines contain very high concentrations of biolimiting nutrients such as $\mathrm{NH}_{4}$, reduced $\mathrm{C}$, trace metals, $\mathrm{Ba}$, and $\mathrm{Si}$. Recent estimates have shown that the flux of nutrients from a large sedex hydrothermal system can exceed the modern riverine flux into the ocean (Emsbo and others, 2005; Emsbo, 2008). Such an immense nutrient flux into a single sedimentary basin would undoubtedly cause massive increases in primary productivity. Resulting eutrophication would establish anoxic conditions and preserve organic matter. Variations in the redox state of the brine discharged can explain the extraordinary metal enrichments and some of the compositional variation in the black shales (Emsbo and others, 2005; Emsbo, 2008). However, the low solubility of phosphate in hydrothermal fluids suggests that it was not introduced by the brines. A plausible phosphate source, other than seawater, might be remobilization of phosphate adsorbed on detrital ferric oxyhydroxides as the seas become anoxic. An appealing aspect of this phosphate source is that it explains the temporal and spatial coincidence of phosphate and sedex deposits. Overall, the enormous flux of biolimiting nutrients and metals delivered to the ocean by hydrothermal fluids may have been sufficient to form the metal deposits and trigger basin-wide anoxia and the associated biological and chemical changes in the sedimentary basin.

\section{Deduced Geologic Assessment Criteria}

- Basin-wide organic-rich metalliferous black shales and $\mathrm{PO}_{4}, \mathrm{Fe}$, and $\mathrm{Mn}$ deposits may identify prospective sedimentary intervals in basins.

- Zoning of metals and metal ratios can be used as local vectors toward areas with mineralization.

\section{Hierarchy of Geologic Exploration and Resource Assessment Criteria}

Figure 2 summarizes the ore genesis model and the geologic assessment criteria deduced from empirical data and the current understanding of the physicochemical, geologic, and mass balance constraints on sedex-ore formation. Below, it is demonstrated how these geologic criteria can be used in the Updated National Assessment to define permissive tracts, assess the relative prospectivity of permissive tracts, and map favorability within permissive tracts. In each section, the criteria are ranked according to their relative importance. 


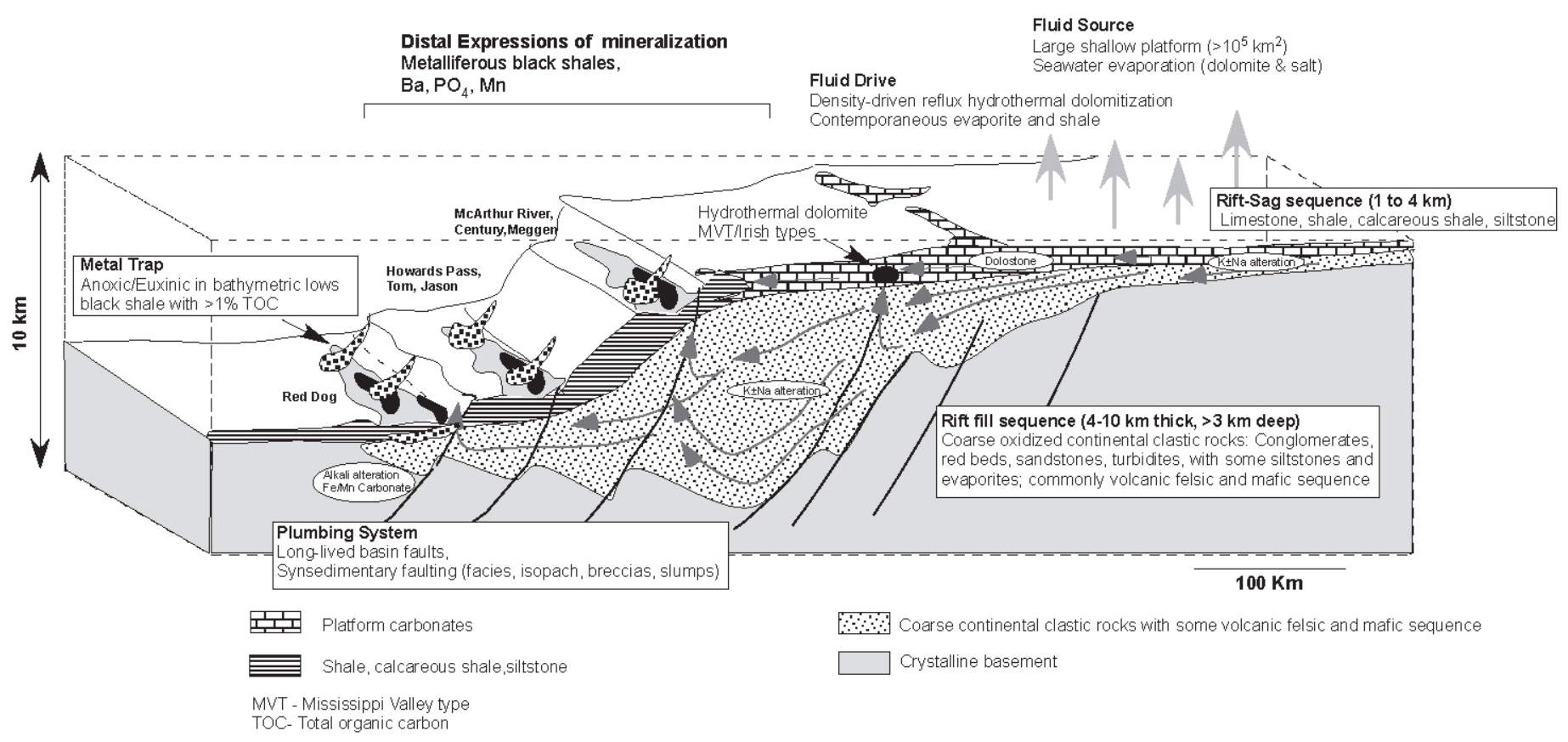

Figure 2. Geologic setting and geologic assessment criteria for sedex Zn-Pb-Ag deposits that are deduced form this synthesis (see text for descriptions). Gray arrows represent fluid-flow paths inferred from the distribution of altered rocks and an ongoing (in 2009) U.S. Geological Survey numerical fluid flow-modeling project. The locations of several important sedex deposits relative to the shallow-water platform margin are indicated and may reflect the structural architecture of the basin or the maturity of the rift cycle.

\section{Geologic Criteria that Define Permissive Tracts}

Central to the existing U.S. Geological Survey mineral assessment protocol is the determination of permissive tracts. Boundaries of permissive tracts are defined as areas outside which the probability of a deposit occurring is negligible. This analysis has identified geologic criteria that can be used as a proxy for geologic processes essential for sedex formation. It is also important that the geologic criteria used be able to define permissive tracts at the scale of a regional assessment $(1: 500,000)$. In order for an area to be considered permissive, it must have the following attributes.

- Intracratonic or epicratonic sedimentary basin: All sedex deposits occur in intracratonic or epicratonic sedimentary basins. Thus an intracratonic or epicratonic sedimentary basin is a prerequisite for this deposit type.

- Depth to crystalline basement greater than $3 \mathrm{~km}$ : It has been well established that fluid temperatures in excess of $100^{\circ} \mathrm{C}$ are required to form a sedex deposit. Empirical observations and the current understanding of the thermal regimes of sedimentary basins indicate that at least 3 kilometers of sediment fill is required to achieve these temperatures.

- Organic-rich black shale or siltstone with greater than 1 percent $\mathrm{C}_{\text {org: }}$ : A shale unit with greater than 1 percent $\mathrm{C}_{\text {org }}$ is essential for sedex-ore formation and must be identified for an area to be permissive.

- Brine salinity source: Saline brine (>17 percent TDS) is necessary to form a sedex deposit. Basinscale processes are required to produce the volume of brine necessary to form a deposit. Thus, direct geologic evidence for saline brine generation (such as evaporite minerals, breccias indicating salt dissolution or escape, or regional dolomitized platforms sequences) is required. In the rare case 
where platform margins are obscured or missing owing to erosion or tectonic disruption, paleolatitude reconstructions can be used to determine if a basin was at a latitude permissive of seawater evaporation during its history.

\section{Geologic Criteria Used to Evaluate the Prospectivity of Permissive Tracts}

Many of the defined geologic criteria, though not adequate to limit permissive tracts, directly implicate basin and hydrothermal processes that may influence estimates of number, size, and density of undiscovered deposits within permissive tracts, defined here as tract prospectivity. Such criteria are listed below in order of decreasing importance.

- Already discovered sedex deposits or occurrences: All known sedex basins contain multiple deposits in multiple horizons. Thus, the occurrence of sedex-ore mineralization is the strongest indicator of a prospective basin.

- Coeval evaporative platform and organic-rich basinal sediments: The analysis of the six most fertile sedex-ore-hosting basins reveals that they contain 12 mineralizing episodes that correspond with discrete periods of intense evaporation of seawater on the platform and the formation of regional shales anomalously enriched in organic matter. The implication is that these phenomena are related to sedex ore formation and that their coincident occurrence is a strong indicator of sedex-ore formation.

- Large evaporative shallow-water marine epeiric carbonate platform margins: The empirical and genetic relationships documented here suggest that carbonate platforms are the source of ore brines and provide the fluid drive to form sedex deposits. The occurrence of multiple episodes of mineralization in the six most-fertile sedex basins suggests that, once the proper basin architecture is established, sedex deposits will form when the basin is exposed to the proper climatic and plaeolatitude conditions for brine generation.

- Oxidized rift-phase sediments: Empirical observation, radiogenic isotope studies, and chemical or fluid-flow modeling show that 2-4-km-thick sequences of syn-rift coarse, continental, clastic sediments (conglomerates, red beds, sandstones, turbidites, and subordinate volcanic successions) provided the metals for sedex deposits. Oxidized (low $\mathrm{C}_{\text {org }}$ and high reactive $\mathrm{Fe}$ ), permeable sequences at depths greater than $3 \mathrm{~km}$ are ideal. Mass balance estimates of leachable metal suggest that the volume of these rocks within a given basin may provide an upper limit to the total amount of metal available for ore formation.

- Evidence of hydrothermal activity: The large volume of fluids required to form sedex deposits leave alteration footprints that can be recognized on the basin scale. This evidence can include extensive dolomitization of platform carbonate rocks and pervasive alkali-alteration of clastic sediment aquifers. On the local scale, strong mineralogical and chemical alteration along growth faults and alteration and metal halos can be used to vector toward the deposits.

- Distal signatures of mineralization: Regional shales anomalous in $\mathrm{C}_{\text {org }}$, metals, and sedimentary $\mathrm{Ba}$, $\mathrm{Mn}, \mathrm{Fe}$, and $\mathrm{PO}_{4}$ deposits are strong indicators of sedex deposits.

- Chemical composition of already discovered mineralization: Varying proportions of base metals, barite, and gold may ultimately reflect the lithology and redox buffering capacity of basin-fill sediments in the metal source regions, which may be a highly useful indicator for deposit formation, metal endowment, and prospectivity of a sedimentary basin.

- Age of the basin: The requirement of marine sulfate as a source of reduced sulfur may limit sedex deposit formation to Proterozoic and Phanerozoic time. The correspondence of known sedex deposits with regional, and perhaps global, anoxic events may identify periods of time that are favorable for additional discoveries. 


\section{Geologic Criteria that Map Favorability within Permissive Tracts}

- Basin architecture: On a regional scale, areas within tens of kilometers of large, long-lived basinbounding faults that controlled second-order basin features are highly favorable. The close association of synsedimentary faults (recognized by features in the regional to local stratigraphy or basin architecture such as abrupt and truncated facies boundaries in platform-to-slope transition, thick debris flows, intraformational breccias, changes in isopachs, and synsedimentary slump structures) indicates favorable stratigraphic horizons and can be used to vector toward structures that may have been ore-fluid conduits.

- Geochemical anomalies or zoning: On a local scale, increasing organic matter and pyrite, and trace element concentrations (and ratios) in reduced sediments can be used as vectors toward areas favorable for ore. Hydrothermal alteration composed of Fe- and Mn-rich carbonate rocks or silicification (or both) allows identification of mineralizing faults on a local scale.

- Sedex deposits or occurrences: It is common for multiple sedex deposits to be distributed many tens of kilometers along basin-controlling faults. Thus, areas along large fault systems with evidence of mineralization should be viewed as very favorable for undiscovered deposits.

\section{Potential Environmental Impacts of Sedex Deposits}

Kelley and others (1995) summarized the important environmental considerations associated with sedex deposits. They suggested that deposits lacking associated carbonate rock have a high potential for generating natural acid drainage with high metal concentrations. Acid-drainage generation depends on (1) the amount of iron-sulfide present, (2) the type of iron sulfide mineral or minerals in the deposit (reactivity decreases from pyrrhotite to marcasite to pyrite), and (3) the extent to which the deposit is exposed to air and water. In extreme cases drainage water may contain thousands of milligrams per liter of $\mathrm{SO}_{4}$; hundreds of milligrams per liter of $\mathrm{Fe}, \mathrm{Zn}, \mathrm{Mn}, \mathrm{Pb}, \mathrm{Cd}, \mathrm{Cu}, \mathrm{Fe}$; tens of milligrams per liter of $\mathrm{Al}$; and tens of micrograms per liter of $\mathrm{Co}$. In terrains dominated by fine-grained, low-carbonate clastic and volcanic rocks, potential downstream environmental effects of natural acid drainage can be pervasive and extend as far as $30 \mathrm{~km}$ downstream. In contrast, deposits with associated carbonate rocks or abundant carbonate alteration minerals have more limited potential for acid-drainage generation, which keeps most metal concentrations low. Oxidative weathering may form Fe-rich gossans above some deposits. Depending on wall-rock buffering capacity, iron content of the ore, and metal-sulfur ratios of sulfide minerals, the gossan environment can be acidic with $\mathrm{pH}<5$. Some gossans may also contain soluble secondary lead-manganese minerals as well as secondary sulfates of iron, aluminum, and potassium that can dissolve during periodic storms giving rise to short-term pulses of highly acidic, metal-bearing surface waters.

\section{References Cited}

Ansdell, K.M., Nesbitt, B.E., and Longstaffe, F.J., 1989, A fluid inclusion and stable isotopic study of the Tom Ba-Pb-Zn deposit, Yukon Territory, Canada: Economic Geology, v. 84, p. 841-856. Armstrong, P.A., 2005, Thermochronometers in sedimentary basins: Reviews in Mineralogy and Geochemistry, v. 58, p. 499-525.

Ayuso, R.A., Kelley, K.D., Leach, D.L., Young, L.E., Slack, J.F., Wandless, J.F., Lyon, A.M., and Dillingham, J.L., 2004, Origin of the Red Dog Zn-Pb-Ag deposits, Brooks Range, Alaska-Evidence from regional $\mathrm{Pb}$ and $\mathrm{Sr}$ isotope sources: Economic Geology, v. 99, no. 7, p. 1533-1553.

Badham, J.P.N., 1981, Shale-hosted Pb-Zn deposits—Products of exhalation of formation waters?:

Transactions, Institution of Mining and Metallurgy. Section B: Applied Earth Science, v. 90, p. 70-76. 
Berner, R., and Raiswell, R., 1983, Burial or organic carbon and pyrite in sediments over Phanerozoic time-A new theory: Geochimica et Cosmochimica Acta, v. 47, p. 885-862.

Bethke, C.M., 1985, A numerical model of compaction-driven groundwater flow and heat transfer and its application to the paleohydrology of intracratonic sedimentary basins: Journal of Geophysical Research, v. 90, p. 6817-6828.

Bresser, H.A., 1992, Origin of base metal vein mineralization in the Lawn Hill mineral field, north western Queensland: Townsville, James Cook University, B.Sc. thesis, 115 p.

Carne, R.C., and Cathro, R.J., 1982, Sedimentary exhalative (sedex) zinc-lead-silver deposits, northern Canadian Cordillera: CIM Bulletin (1974), v. 75, no. 840, p. 66-78.

Carpenter, A.B., 1978, Origin and chemical evolution of brines sedimentary basins: Oklahoma Geological Survey Circular, v. 79, p. 60-77.

Cathles, L.M., and Adams, J.J., 2005, Fluid flow and petroleum and mineral resources in the upper $(<20-\mathrm{km})$ continental crust, in Hedenquist, J.W., Thompson, J.F.H., Goldfarb, R.J., and Richards, J.P., eds., Economic Geology-One hundredth anniversary volume, 1905-2005: Society of Economic Geologists, p. 77-110.

Clauser, C., and Huenges, E., 1995, Thermal conductivity of rocks and minerals, in Rock physics and phase relations, a handbook of physical constants, AGU Reference Shelf: Washington, D.C., American Geophysical Union, p. 105-126.

Cooke, D.R., Bull, S.W., Large, R.R., McGoldrick, P.J., Lydon, J.W., and Anonymous, 2000, The importance of oxidized brines for the formation of Australian Proterozoic stratiform sediment-hosted $\mathrm{Pb}-\mathrm{Zn}$ (sedex) deposits: Economic Geology, v. 95, no. 1, p. 1-18.

Davidson, G.J., 1998, Alkali alteration styles and mechanisms, and their implications for a "brine factory" source of base metals in the rift-related McArthur Group, Australia: Australian Journal of Earth Sciences, v. 45, no. 1, p. 33-49.

Einsele, G., 2000, Sedimentary basins_-Evolution, facies, and sediment budget: Berlin, Springer, 792 p. Emsbo, Poul, 2000, Gold in sedex deposits: Reviews in Economic Geology, v. 13, p. 427-437.

Emsbo, Poul, 2004, Genetic links among syngenetic metal accumulations in sedimentary basins - Giant sediment-hosted metal deposits to metalliferous black shales: GSA Abstracts with Programs, v. 36, no. 5 , p. 199.

Emsbo, Poul, 2008, Metalliferous organic-rich black shales-Are exhalative hydrothermal processes fundamental to their genesis? [abs.]: International Geological Congress Abstracts, Oslo, v. 33, abstract no. 1324230 .

Emsbo, Poul, Groves, D.I., Hofstra, A.H., and Bierlein, F.P., 2006, The giant Carlin gold province; a protracted interplay of orogenic, basinal, and hydrothermal processes above a lithospheric boundary: Mineralium Deposita, v. 41, no. 6, p. 517-525.

Emsbo, Poul, Hofstra, A.H., Johnson, C.A., Koenig, A., Grauch, R., Zhang Xingchun, Hu Ruizhong, Su Wenchao, and Pi Daohui, 2005, Lower Cambrian metallogenesis of south China; interplay between diverse basinal hydrothermal fluids and marine chemistry, in Mao, J., and Bierlein, P.F., eds., Mineral Deposit Research: Meeting the Global Challenge Proceedings of the Eighth Biennial SGA Meeting Beijing, China, p. 115-118.

Emsbo, Poul, Hutchinson, R.W., Hofstra, A.H., Volk, J.A., Bettles, K.H., Baschuk, G.J., and Johnson, C.A., 1999, Syngenetic Au on the Carlin trend: Implications for Carlin-type deposits: Geology, v. 27, no. 1, p. 59-62.

Emsbo, Poul, and Johnson, C.A., 2004, Formation of modern and Paleozoic stratiform barite at cold methane seeps on continental margins - Comment: Geology, v. 32, p. e64.

Gardner, H.D., and Hutcheon, I., 1985, Geochemistry, mineralogy, and geology of the Jason Pb-Zn deposits, Macmillan Pass, Yukon, Canada: Economic Geology, v. 80, p. 1257-1276. 
Garven, G., Bull, S.W., and Large, R.R., 2001, Hydrothermal fluid flow models of stratiform ore genesis in the McArthur Basin, Northern Territory, Australia: Geofluids, v. 1, no. 4, p. 289-311.

Garven, G., Raffensperger, J.P., Dumoulin, J.A., Bradley, D.C., Young, L.E., Kelley, K.D., and Leach, D.L., 2003, Coupled heat and fluid flow modeling of the Carboniferous Kuna Basin, AlaskaImplications for the genesis of the Red Dog Pb-Zn-Ag-Ba ore district: Journal of Geochemical Exploration, v. 78-79, no. 2003, p. 215-219.

Goodfellow, W.D., and Lydon, J.W., 2007, Sedimentary exhalative (SEDEX) deposits, in Goodfellow, W.D., ed., Mineral deposits of Canada-A synthesis of major deposit-types, district metallogeny, the evolution of geological provinces, and exploration methods: Geological Association of Canada, p. $163-184$.

Goodfellow, W.D., Lydon, J.W., and Turner, R.J.W., 1993, Geology and genesis of stratiform sedimenthosted (SEDEX) zinc-lead-silver sulphide deposits, in Kirkham, R.V., Sinclair, W.D., Thorpe, R.I., and Duke, J.M., eds., Mineral deposit modeling, p. 201-251.

Hanor, J.S., 1994, Origin of saline fluids in sedimentary basins, in Parnell, J., ed., Geofluids_-Origin, migration and evolution of fluids in sedimentary basins: Geological Society [London] Special Publications, p. 151-174.

Hanor, J.S., 1996, Controls on the solubilization of lead and zinc in basinal brines, in Sangster, D.F., ed., Carbonate-hosted lead-zinc deposits: Society of Economic Geology Special Publication, p. 483-500. Hunt, J.M., 1996, Petroleum geochemistry and geology: New York, Freeman, 743 p.

Hutchinson, R.W., 1980, Massive base metal sulphide deposits as guides to tectonic evolution: Geological Association of Canada Special Paper 20, p. 659-684.

Johnson, C.A., Emsbo, P., Poole, F.G., and Rye, R.O., 2009, Sulfur and oxygen isotopes in sedimenthosted stratiform barite deposits: Geochimica et Cosmochimica Acta, v. 73, no. 1, p. 133-147.

Johnson, K.M., Doebrich, J.L., du Bray, E.A., Foley, N., 2008, Mineral deposits research required for the next national mineral resource assessment - a collaborative opportunity: Geological Society of America Abstracts with Programs, v. 40, no. 1, p. 50.

Jones, G.D., Whitaker, F.F., Smart, P.L., and Sanford, W.E., 2002, Fate of reflux brines in carbonate platforms: Geology, v. 30, p. 371-374.

Kelley, K.D., Dumoulin, J.A., and Jennings, S., 2004, The Anarraaq Zn-Pb-Ag and barite deposit, northern Alaska - Evidence for replacement of carbonate by barite and sulfides: Economic Geology, v. 99, no. 7, p. 1577-1591.

Kelley, K.D., Seal, R.R., Schmidt, J.M., Hoover, D.B., and Klein, D.P., 1995, Sedimentary exhalative $\mathrm{Zn}-\mathrm{Pb}$-Ag deposits, in du Bray, E.A., ed., Preliminary compilation of descriptive geoenvironmental mineral deposit models: USGS Open-File Report p. 225-233.

Kharaka, Y.K., Maest, A.S., Carothers, W.W., Law, L.M., Lamothe, P.J., and Fries, T.L., 1987, Geochemistry of metal-rich brines from central Mississippi Salt Dome Basin, U.S.A: Applied Geochemistry, v. 4, p. 543-561.

Kreuzer, O.P., Etheridge, M.A., Guj, P., McMahon, M.E., and Holden, D.J., 2008, Linking mineral deposit models to quantitative risk analysis and decision-making in exploration: Economic Geology, v. 103 , no. 4, p. 829-850.

Large, D.E., 1980, Geological parameters associated with sediment-hosted, submarine exhalative $\mathrm{Pb}-\mathrm{Zn}$ deposits-An empirical model for mineral exploration: Geologisches Jahrbuch, v. D40, p. 59-129.

Large, D.E., 1983, Sediment-hosted massive sulphide lead-zinc deposits-An empirical model, in Sangster, D.F., ed., Sediment-hosted stratiform lead-zinc deposits: Mineralogical Association of Canada, p. 1-29.

Large, R., Bull, S.W., Cooke, D., and McGoldrick, P., 1996, Review of genetic models at HYCConstraints from new sedimentology, alteration halo studies and fluid chemical modelling: 
Contributions of the Economic Geology Research Unit, v. 55, p. 72-74.

Large, R., McGoldrick, P.J., Bull, S.W., and Cooke, D., 2004, Controls on the formation of giant stratiform sediment-hosted $\mathrm{Zn}-\mathrm{Pb}$-Ag deposits - With particular reference to the north Australian Proterozoic: Hobart, University of Tasmania, CODES special publication 4, p. 107-149.

Large, R.R., Bull, S.W., Cooke, D.R., McGoldrick, P.J., Zheng Libo, Ye Ying, Zhou Huaiyang, and Wang Huaizhao, 1998, A genetic model for the H.Y.C. deposit, Australia, based on regional sedimentology, geochemistry, and sulfide-sediment relationships: Economic Geology, v. 93, no. 8, p. 1345-1368.

Large, R.R., Bull, S.W., McGoldrick, P.J., Walters, S., Derrick, G.M., and Carr, G.R., 2005, Stratiform and stratabound $\mathrm{Zn}-\mathrm{Pb}-\mathrm{Ag}$ deposits in Proterozoic sedimentary basins, northern Australia: Society of Economic Geologists, 931-963 p.

Large, R.R., and McGoldrick, P.J., 1998, Lithogeochemical halos and geochemical vectors to stratiform sediment hosted Zn-Pb-Ag deposits—-1. Lady Loretta Deposit, Queensland: Journal of Geochemical Exploration, v. 63, no. 1, p. 37-56.

Le Tran, K.J., 1972, Geochemical study of hydrogen sulfide adsorbed in sediments, in von Gaertner, H.R., and Wehner, H., eds., Advances in Organic Geochemistry: Oxford, Pergamon Press, p. 717-726.

Leach, D., Marsh, E., Bradley, D., Gardoll, S., and Huston, D., 2005a, The distribution of sedex Pb-Zn deposits through Earth history: Proceedings of the Biennial SGA Meeting, v. 8, Vol. 1, p. 145-148.

Leach, D.L., Marsh, E., Emsbo, P., Rombach, C.S., Kelley, K.D., and Anthony, M., 2004, Nature of Hydrothermal Fluids at the Shale-Hosted Red Dog Zn-Pb-Ag Deposits, Brooks Range, Alaska: Economic Geology, v. 99, no. 7, p. 1449-1480.

Leach, D.L., Sangster, D.F., Kelley, K.D., Large, R.R., Garven, G., Allen, C.R., Gutzmer, J., and Walters, S., 2005b, Sediment-hosted lead-zinc deposits; a global perspective, in Hedenquist, J.W., Thompson, J.F.H., Goldfarb, R.J., and Richards, J.P., eds., Economic Geology; one hundredth anniversary volume, 1905-2005: Littleton, CO, Society of Economic Geologists, p. 561-607.

Leventhal, J.S., 1983, An interpretation of carbon and sulfur relationships in Black Sea sediments as indicators of environments of deposition: Geochimica et Cosmochimica Acta, v. 47, p. 133-137.

Lin, G., Nunn, J.A., and Deming, D., 2000, Thermal buffering of sedimentary basins by basement rocks: implications arising from numerical simulations: Petroleum Geoscience, v. 6, p. 299-307.

Lydon, J.W., 1983, Chemical parameters controlling the origin and deposition of sediment-hosted stratiform lead-zinc deposits, Short Course Handbook v. 8: Mineralogical Association of Canada, p. $175-250$.

Lydon, J.W., 1986, Models for the generation of metalliferous hydrothermal systems within sedimentary rocks, and their applicability to the Irish Carboniferous $\mathrm{Zn}-\mathrm{Pb}$ deposits, in Andrew, C.J., Crowe, R.W.A., Finlay, S., Pennell, W.M., and Pyne, J.F., eds., Geology and genesis of mineral deposits in Ireland: Dublin, Irish Association for Economic Geology, p. 555-577.

Lydon, J.W., 1995, Sedimentary exhalative sulphides (SEDEX), in Eckstrand, O.R., Sinclair, W.D., and Thorpe, R.I., eds., Geology of Canadian mineral deposit types, p. 130-152.

Lydon, J.W., 2004, Geology of the Belt-Purcell Basin and Sullivan Deposit, in Deb, M., and Goodfellow, W.D., eds., Sediment-hosted lead-zinc sulphide deposits; attributes and models of some major deposits in India, Australia and Canada: New Delhi, Narosa Publishing House, p. 100-148.

Lyons, T.W., Gellatly, A.M., McGoldrick, P.J., and Kah, L.C., 2006, Proterozoic sedimentary exhalative (SEDEX) deposits and links to evolving global ocean chemistry: Memoir - Geological Society of America, v. 198, p. 169-184.

Moldovanyi, E.P., and Walter, L.M., 1992, Regional trends in water chemistry, Smackover Formation, Southwest Arkansas: Geochemical and physical controls: American Association of Petroleum Geologists Bulletin, v. 76, p. 864-894. 
Neuzil, C.E., 1995, Abnormal pressures as hydrodynamic phenomena: American Journal of Sciences, v. 295, p. 742-786.

Polito, P.A., Kyser, T.K., Golding, S.D., and Southgate, P.N., 2006, Zinc Deposits and Related Mineralization of the Burketown Mineral Field, Including the World-Class Century Deposit, Northern Australia: Fluid Inclusion and Stable Isotope Evidence for Basin Fluid Sources: Economic Geology, v. 101, no. 6, p. 1251-1273.

Raffensperger, J.P., and Vlassopoulos, D., 1999, The potential for free and mixed convection in sedimentary basins: Hyrdogeology Journal, v. 7, p. 505-520.

Rittenhouse, G., 1967, Bromide in oilfield waters and its use in determining possibilities of origins its waters: American Association of Petroleum Geologists Bulletin v. 51, no. 2430-2440.

Rollkotter, J., 2006, Organic matter-The driving force for early diagenesis, in Schulz, H.D., and Zabel, M., eds., Marine Geochemistry: New York, Springer, p. 125-166.

Russell, M.J., Solomon, M., and Walshe, J.L., 1981, The genesis of sediment-hosted exhalative zinc and lead deposits: Mineralium Deposita, v. 16, p. 113-127.

Sangster, D.F., 2002, The role of dense brines in the formation of vent-distal sedimentary-exhalative (SEDEX) lead-zinc deposits_-Field and laboratory evidence: Mineralium Deposita, v. 37, no. 2, p. $149-157$.

Sangster, D.F., and Hillary, E.M., 2000, SEDEX lead-zinc deposits-Proposed subtypes and their characteristics: Exploration and Mining Geology, v. 7, p. 341-357.

Sawkins, F.J., 1984, Ore genesis by episodic dewatering of sedimentary basins-Application to giant Proterozoic lead-zinc deposits: Geology, v. 12, p. 451-454.

Southgate, P.N., Kyser, T.K., Scott, D.L., Large, R.R., Golding, S.D., and Polito, P.A., 2006, A basin system and fluid-flow analysis of the $\mathrm{Zn}-\mathrm{Pb}-\mathrm{Ag}$ Mount Isa-type deposits of northern AustraliaIdentifying metal source, basinal brine reservoirs, times of fluid expulsion, and organic matter reactions: Economic Geology, v. 101, no. 6, p. 1103-1115.

Tikkanen, G.D., 1986, World resources and supply of lead and zinc, in Bush, W.R., ed., Economics of internationally traded minerals: Society of Mining Engineers, p. 242-250.

Turcotte, D.L., and Schubert, G., 1982, Geodynamics: New York, John Wiley, 450 p.

Turner, R.J.W., 1992, Formation of Phanerozoic stratiform sediment-hosted zinc-lead depositsEvidence for the critical role of ocean anoxia: Chemical Geology, v. 99, p. 165-188.

Walter, L.M., Stuebler, A.M., and Huston, T.J., 1990, Br-Cl-Na systematics in Illinois basin fluidsConstraints on fluid origin and evolution: Geology, v. 18, p. 315-318.

Warren, J.K., 2006, Evaporites—Sediments, resources, and hydrocarbons: New York, NY, Springer, $1035 \mathrm{p}$.

Yang, J., Bull, S., and Large, R., 2004, Numerical investigation of salinity in controlling ore-forming fluid transport in sedimentary basins_-Example of the HYC Deposit, northern Australia: Mineralium Deposita, v. 39, no. 5-6, p. 622-631.

Yang, J., Large, R.R., Bull, S., and Scott, D.L., 2006, Basin-scale numerical modeling to test the role of buoyancy-driven fluid flow and heat transfer in the formation of stratiform $\mathrm{Zn}-\mathrm{Pb}-\mathrm{Ag}$ deposits in the northern Mount Isa Basin: Economic Geology, v. 101, no. 6, p. 1275-1292.

Zielinski, R.A., Bloch, S., and Walker, T.R., 1983, The mobility and distribution of heavy metals during the formation of first cycle red beds: Economic Geology, v. 78, no. 8, p. 1574-1589. 